Uncorrected preprint. Please cite as:

Brankovic, J., Ringel, L., \& Werron, T. (2021). Theorizing University Rankings by Comparison: Systematic and historical analogies with arts and sports. In E. Hazelkorn \& G. Mihut (Eds.), Research Handbook on University Rankings: History, Methodology, Influence and Impact. Edward Elgar Publishing.

\title{
Theorizing University Rankings by Comparison: Systematic and historical analogies with arts and sports
}

\author{
Jelena Brankovic ${ }^{1}$, Leopold Ringel ${ }^{2}$, Tobias Werron \\ Faculty of Sociology, Bielefeld University
}

\begin{abstract}
In this paper we lay down a comparative framework for theorizing university rankings, which can be used and further extended by scholars interested in advancing research on rankings. In so doing, we contextualize the analysis of university rankings within a broader sociology of rankings. We identify two dimensions along which such contextualization could be done: (a) systematic, referring to the comparison of university rankings with rankings in other fields and focusing on how university rankings can be informed by insights from other empirical settings; and (b) historical, which concerns long-term trajectories, rather than just the past few years. We argue that analogical theorizing is one promising strategy for doing this, and to illustrate its potential, we bring insights from the arts and sports fields into the study of university rankings. This approach, we argue, can benefit both our understanding of university rankings and rankings more generally.
\end{abstract}

Keywords: rankings, comparison, analogical theorizing, universities, arts, sports

${ }^{1}$ ORCID: 0000-0002-0485-9096

2 ORCID: 0000-0002-4894-3337 


\section{Introduction}

For more than a decade now, rankings have occupied a central place in the higher education and science studies (Hazelkorn 2015). Scholars across the social science disciplines have contributed to the debate on what constitutes rankings, how and why they are produced, and especially how rankings affect higher education. This has resulted in an impressive and still growing body of literature on the topic of university rankings alone. Meanwhile, rankings have dramatically proliferated. Various rankings can now be found in a growing number of fields ${ }^{3}$, as well as at virtually any level from local to global. Restaurants, firms, hospitals, nation-states, cities, tourist attractions, and individuals, are only some of the entities which, willingly or not, are being regularly subjected to the evaluation exercises for the purpose of creating national, regional, and international league tables.

Yet when it comes to the study of rankings, save for a handful of exceptions (e.g. de Rijcke et al. 2016; Ringel et al. 2020; Soh 2011; Tight 2000), this research has by and large remained within the boundaries of a single field. The absence of comparative research on rankings across fields, as well as of theoretical and conceptual linkages which would emerge from such studies, is certainly one of the reasons why we still do not have an overarching framework which could guide empirical research on rankings across contexts. A comparative approach spanning sectors would not only lead to a higher level of generality, but would also benefit our understanding of what is happening in specific fields, including that of higher education (Lamont 2012; Vaughan 2014).

Furthermore, the research on university rankings, and consequently our knowledge thereof, is strikingly ahistorical. Even though academic rankings have been around for more than a century (Myers and Robe 2009; Ringel and Werron 2020), the research on contemporary university rankings is rarely interested in systematic comparison between the early and later forms of rankings. We argue that, in order to advance our theoretical work, we should pay attention to how rankings in a single field emerge and evolve, and look for broader historical and institutional conditions that have shaped the ranking practice over the course of the twentieth century and more recently.

\footnotetext{
${ }^{3}$ We use the notion of 'field' to refer to areas of practice in the most general sense. We do acknowledge that the fields we refer to here, such as higher education, sports and the arts, are constituted of multiple sub-fields that make use of rankings in a variety of ways.
} 
In this chapter we lay down a framework for theorizing university rankings which could be useful for guiding empirical analyses. The framework can be applied to the study of rankings along two dimensions: (a) systematic, which concerns the comparison of university rankings with rankings in other fields; and (b) historical, which concerns long-term trajectories. Using these two dimensions, we wish to contextualize the analysis of university rankings within a broader sociology of rankings, as well as offer a framework for advancing the sociological theory of rankings. We draw attention to the potential of analogical theorizing. To illustrate this, we examine the evidence from the arts and sports fields and show how such evidence can benefit both our understanding of university rankings and rankings more generally.

\section{Comparative research beyond higher education as a way of advancing the theorizing of university rankings}

In much of the literature, university rankings are implicitly assumed to be, or are treated as, a relatively recent phenomenon which has come as a result of, among others, neoliberal policies, the rise of the audit culture, and the worldwide diffusion of Western cultural models in the post-WWII period (e.g. Lynch 2015; Ramirez and Meyer 2013; Shore and Wright 2015). Despite their relative recency as an object of interest, they have inspired a remarkable body of work, which has undoubtedly led not only to the university rankings being the most studied of all, but also to a better understanding of rankings in general (see Rindova et al. 2018 for a comprehensive review).

Meanwhile, comparative studies are a well-established area of research in higher education (Kosmützky and Nokkala 2020; Teichler 2014). However, this tradition of scholarship is primarily, if not exclusively, interested in comparisons within higher education, although the scholars have called for a greater awareness of the limits of current approaches and a more systematic engagement with broader scholarship (e.g. Kosmützky 2015; Pinheiro et al. 2016; Shahjahan and Kezar 2013). When it comes to the research on university rankings, there seems to be little interest in the dynamics related to rankings and similar phenomena in other sectors. By way of illustration, if we look at the reference lists of the most cited works on rankings in higher education, in particular those in specialized outlets, we can find few works on rankings in other fields. This is, however, less often the case in other fields, where the studies on higher education rankings are more likely to be cited (e.g. Buckermann 2018; Jeacle and Carter 2011; Kelley and Simmons 2015; Kornberger and Carter 2010; Quak et al. 
2019). To some extent, this could be explained by the previously mentioned prevalence of university rankings in the larger body of social science literature, including widely read disciplinary journals (e.g. Elsbach and Kramer 1996; Espeland and Sauder 2007; Rindova et al. 2005).

The importance of a greater attentiveness to the variation across fields in advancing our understanding of rankings was also recognized by Espeland and Sauder (2007) in their seminal study on college rankings in the US. We add to this a further call for a more methodical exploration of the potentials of comparative studies which extend both beyond higher education and beyond the present. This means, among others, asking how rankings vary and do not vary across fields. It also means sensitizing the research for questions of more general theoretical concern, such as, why and how rankings diffuse across fields; how and why contemporary rankings are different than earlier ones; which conditions make rankings not only possible but also more likely today; or, why it is that of all rankings, scholars tend to be mostly interested in the academic ones.

We argue that these and similar questions could be fruitfully addressed with a comparative research agenda, which would draw on insights from other sectors, as well as examine university rankings as a historical phenomenon, and not merely a contemporary one (Deville et al. 2016; Lamont 2012; Mahoney and Rueschemeyer 2003). In principle, this implies searching for similarities across contexts, identifying sources of variation, or both (Ragin and Zaret 1983; Stinchcombe 1978; Swedberg 2016). This search can be twofold. First, it can refer to the systematic comparisons of a phenomenon at a single point in time. Here we emphasize the cross-sectoral aspect because we wish to distinguish between comparing, for example, the university and the corporate sectors, from doing comparisons within a sector at a single point in time.

The second kind of comparison we draw attention to aims to capture the changing sociohistorical circumstances which make the emergence and the institutionalization of rankings possible in specific fields. We refer to this type of comparisons as historical. Here the focus is either on a single field, in this case higher education, and would mean looking at how rankings evolved from their conception to the present day, or during a particular period. Notable exceptions on the side (e.g. Hammarfelt et al. 2017; Myers and Robe 2009), scholars interested in rankings rarely turn to history as a way to identify more enduring properties of rankings, or as a strategy to sharpen their analytical focus on the present circumstances. An alternative strategy regarding the historical analysis would be to compare trajectories and 
possibly identify stages of rankings' institutionalization in different domains, and determinants thereof.

Given that comparative research on rankings across sectors requires working with structurally different contexts, we suggest exploring alternative methods of theorizing to the 'like and like' kind of comparisons. The works collected in the volume edited by Deville, Guggenheim, and Hrdličková (2016) offer useful examples of such strategies. For example, Krause (2016) distinguishes between the 'like with unlike' comparisons, asymmetrical comparisons, hypothetical comparisons, and undigested comparisons. Which of these strategies should be pursued is, as Krause argues, a question of fitness for purpose. In this sense, we join other higher education scholars who recently called for moving beyond the usual comparative approaches, as well as beyond methods of theorizing which centre on the linear-causal explanations, and in the direction of alternative styles of theorizing which would investigate 'what happened, where it happened, why it happened and how it happened' (Cantwell 2020: 150; Kosmützky et al. 2020).

One such method which has been successfully used in generating theoretical insights is analogical theorizing (Vaughan 2004, 2014). Plainly put, this type of theorizing relies on analogy as a form of comparison (Bartha 2019). Analogical reasoning is also common in everyday life, as well as in specific professional contexts, such as legal practice and education (Hinds-Aldrich 2012; Sunstein 1993). Theorizing across contexts by using analogy is, nevertheless, not so much about systematically screening two instances of plausibly relevant similarities and differences, as much as it is about using insight from other fields to illuminate phenomena in the field of interest (Becker 2014; Buchholz 2016; Swedberg 2016). This, as Vaughan suggests (2014), can be done at every stage of the research process, from case selection, via concept development and theorizing, to generalizing beyond the case. Importantly, it requires one to see theorizing as a process, rather than as an end product (Weick 1995).

Alternative methods of theorizing hold promise for delivering what King, Felin, and Whetten call 'the element of surprise' in theory development (2009: 9). Contrasting different contexts can help us identify aspects of university rankings which the researchers focusing on this sector alone may take for granted, consider common or uninteresting, but which may stand out as unique to this sector when compared to others. It could also help elucidate certain structural differences between rankings and other types of third-party evaluations, such as ratings and benchmarks. Similarly, historical comparisons could draw our attention to 
the emergence of new elements in rankings and allow us to see how this specific change affects the entire rankings operation. Such strategies, we argue, have a great deal of potential for advancing the theory.

Finally, looking at one's primary field of inquiry through the lens informed with the evidence from another field requires distancing oneself from the object of interest, which is necessary for a valid judgement in social sciences (Daston 1992; Linstead 1994). We believe this is especially important for scholars studying universities, given that most of us studying rankings are embedded in the organizations which are direct objects of the rankings we are set to study and explain. This is, we contend, not a trivial matter. Quite certainly, it is an additional reason to look beyond higher education and beyond now, and in doing so keep the necessary distance in check.

Table 1. A typology of approaches to the study of university rankings

\begin{tabular}{|c|c|c|}
\hline & Within the university field & Systematic (across fields) \\
\hline Snapshot & $\begin{array}{l}\text { Analysing university rankings at a single } \\
\text { point in time }\end{array}$ & $\begin{array}{l}\text { Comparing university rankings at one point } \\
\text { in time with rankings in another field (e.g. } \\
\text { culinary, sports, etc.) at the same or different } \\
\text { point in time }\end{array}$ \\
\hline Historical & $\begin{array}{l}\text { Establishing field-specific historical } \\
\text { trajectories of university rankings } \\
\text { Comparing university rankings at two or } \\
\text { more points in time }\end{array}$ & $\begin{array}{l}\text { Comparing field-specific historical } \\
\text { trajectories of rankings in the university field } \\
\text { with those of other field(s) }\end{array}$ \\
\hline \multicolumn{3}{|c|}{$\begin{array}{l}\text { Table } 1 \text { summarizes the four comparative strategies. For the analogical theorizing to be } \\
\text { eaningful, Buchholz (2016) suggests the following three steps, which we follow here. We } \\
\text { art with (1) the analytical reduction of theory, we subtract form from content and } \\
\text { sentangle properties from scale. Applied to our case, this means identifying the 'bare' } \\
\text { ements of rankings we wish to examine. Then, we conduct (2) analogical extension. This } \\
\text { actically means identifying structural equivalences between the rankings of interest, in this } \\
\text { se higher education, and rankings we wish to draw analogies from. Finally, we (3) identify } \\
\text { ad interpret relevant empirical differences. }\end{array}$} \\
\hline
\end{tabular}


To illustrate our approach, in the following sections we look at the field-specific evolution of university rankings, we compare our observations systematically and historically ${ }^{4}$ with insights from rankings in two other fields-sports and arts-and highlight similarities and differences of theoretical relevance. We focus on the production of rankings and their institutionalization.

\section{Just like in sports?}

The earliest experiments with ranking universities are today usually attributed to James McKeen Cattell (Myers and Robe 2009). Although at first Cattell was not so much interested in comparing universities for universities' sake, as much as he was in identifying which universities were attended by the so-called 'eminent men' (as an assumed factor in predicting one's eminence), he did eventually produce rankings of scientific institutions according to their 'scientific strength' (Hammarfelt et al. 2017).

At the time, however, numerical representations, including lists and other visual devices, were not uncommon (Beniger and Robyn 1978). Throughout the nineteenth century, population statistics and other kinds of 'social data' became not only more widely and more frequently used, but increasingly more public as well (Mennicken and Espeland 2019). Numbers were getting a historical momentum and their use diffused rapidly across fields. However, rankings, as a means of comparing and evaluating performances, occupy a particular place in the history of statistics (Ringel and Werron 2020). One field in which rankings seem to have been most at home already in the nineteenth century, and which had little to do with population counting for purposes of state bureaucracy, was sports (Guttmann 1978).

In sports, the practice of continuously recording individual achievements, but also of statistically comparing and presenting them to a broad public in form of tables, became an established practice in the mid-to-late nineteenth century (Ringel and Werron 2020; Werron 2009). The emergence of rankings, as opposed to statistics more generally, was closely related to the introduction of new types of competition like the league system. What was new about these competitions, and what triggered the production and publication of rankings, was that

\footnotetext{
${ }^{4}$ For clarification: with historical and systematic, we specifically refer to the type of comparison described in the bottom right cell of Table 1 , and it is this type which we illustrate in this chapter.
} 
they determined the 'winners' based on the outcome of a series of contests over a longer period of time, that is, 'the season'. This makes each contest part of an overarching competitive structure, allowing even 'champions' to lose once in a while as long as they win frequently enough over the course of the season. Such competitions imply a new, statistical idea of sports performance, which prefers consistency over stellar achievements in individual contests, and they require the regular publication of tables which keep the audience up to date about the overall standing in the league competition (Werron 2013).

Cattell's rankings had at least two things in common with the nineteenth century sports rankings, which are of relevance here. First, both sports league tables and Cattell's tables were essentially about comparing performances. Second, in both cases, performances were presented in a numerical table, in which the ranked entities were placed on top of each other, with the highest score at the top. However, unlike in sports, nowhere yet were the data on universities being collected systematically and regularly, to allow for repeated reproduction of the same kinds of tables. This was likely one of the reasons why Cattell never reproduced his tables in which he compared the 'scientific strength' of universities (Hammarfelt et al. 2017).

Throughout the twentieth century, there was a continuous interest in comparing performances of universities and producing different kinds of academic quality rankings, although this kind of thinking about academic institutions seems to have been specific to the US context (Myers and Robe 2009). Yet even in the US, the interest in comparing performances was not followed by the interest in getting universities to compete against each other and this would remain the case for decades after Cattell. Not even reputational surveys, which became a practice in assessing quality of US higher education institutions already in the first half of the twentieth century (Usher 2016), were a sufficient condition in this regard, although their taken-for-granted status was far from irrelevant.

Scholars generally agree that the U.S. News \& World Report undergraduate reputational rankings, which arrived in the 1980s, represent a turning point in the history of rankings (Hazelkorn 2015; Monks and Ehrenberg 1999; Myers and Robe 2009). These rankings were novel in a number of important ways, yet when we compare higher education with sports, two novelties emerge as crucial. First, the U.S. News published its rankings in a highlycirculated news magazine, which also meant that rankings were for the first time produced as news for a far-larger-than-earlier audience. Earlier reputational rankings, in contrast, were meant first and foremost for expert audiences, chiefly scholars, administrators, and policy 
makers. ${ }^{5}$ This 'involvement' of a nation-wide audience in the rankings effectively made the college performance a matter of public discussion and concern in the US higher education context. The notion of a spectating audience also brought higher education rankings one step closer to sports competitions.

The second important novelty brought by the U.S. News was regular publication of rankings. Although the prospect of improving performance by climbing rankings was not new, the U.S. News were the first to introduce regular and soon also a yearly ranking cycle. This effectively rendered change in status both expected and regular. Like in sports, already a century earlier, achievement and excellence were now not something which would be measured once or occasionally; rather, they were becoming contingent upon consistency of performance over longer periods (Ringel and Werron 2020).

At the discursive level, this shifted the focus from performances as something which needed to be adequately defined, measured and presented comparatively, to performances as something which was expected to be improving over time. This accentuated the importance of the zero-sum aspect of a hierarchically ordered table, which unequivocally meant that the improvement of performance of one university, expressed as an upward movement in rank, would in principle mean that some other university would be pushed down. Reputation for performance was therefore rendered scarce, which effectively turned higher education institutions into competitors for obtaining it (Brankovic et al. 2018).

The historical comparison between higher education and sports draws our attention to the elements which need to be in place in order for rankings to 'work' in a specific domain, and these are the zero-sum comparison of performances, quantification, visualization by means of a hierarchical table, and repeated publication (Werron and Ringel 2017). Observing these elements in the context of global university rankings has allowed us to theorize how exactly global university rankings produce competition for scarce symbolic capital, such as global reputation for performance (Brankovic et al. 2018).

\footnotetext{
${ }^{5}$ Even the reputational rankings of graduate departments published in the 1966 Cartter Report, which sold approximately 26,000 copies (Webster 1986), largely fall into this category.
} 


\section{Legitimacy, controversy, and institutionalization}

Both sports and higher education have espoused rankings on a global scale. However, they are worlds apart when it comes to the degree to which rankings and competition are accepted as 'natural'. This draws attention to the importance of considering legitimacy of rankings when accounting for their institutionalization or the absence thereof. To explore dimensions of legitimacy relevant for rankings, we draw an analogy between the contemporary university rankings and the early rankings of artists, both characterized by a degree of ambiguity and contestation.

It is not as widely known that some of the earliest numerical evaluative lists were found in the field of arts, as early as the beginning of the eighteenth century (Spoerhase 2018). Produced by notable art critics and connoisseurs, they would compare artists, such as painters, poets, and musicians. However, these lists were not quite like modern rankings, for at least two reasons. First, they were not published continuously. Like Cattell, these rankers were interested in capturing more enduring facets of artists' work, what some called 'poetic genius' or 'aesthetic worth' (Spoerhase 2018). Second, they did not expect the artists to improve performances by competing with each other, not least because many of those ranked were not alive anymore. This comparison alone suggests that competition and by extension also reactivity-in the sense of Espeland and Sauder's study on law schools rankings (2007) - are contingent on (the social construction of) actorhood (Meyer and Jepperson 2000).

The practice of quantifying aesthetic judgements nevertheless diffused throughout Europe over the course of the eighteenth century, only to disappear at the beginning of the nineteenth century (Ringel and Werron 2020). The circumstances of this are not entirely known, yet it is speculated that it was related to the fact that the rankings' creators were not interested in capturing improvement in performance and encouraging competitive behaviour of artists. Referring to Becker (1982), Ringel and Werron (2020) point out that the abandonment of these early experiments might have had to do with the professionalization of art criticism in the early nineteenth century. Art critics may have found a plurality of critical narrative voices to be superior to singular judgements of worth, such as those implied in rankings, and therefore better aligned with the interests of critics' guilds at the time.

Another possible explanation was that the idea of quantifying performances of artists was not considered legitimate in the discourse of the nineteenth century art critics and writers 
(Spoerhase 2018). The logic of the artistic field dictates that the improvement in performance and especially comparison with others is, after all, not something artists should be concerned with; on the contrary, the world of art is considered fundamentally antagonistic to practices which involve, among others, external recognition or commodification of the artistic expression (Bourdieu 1996). As Becker contends, 'theories of art and criteria by which art, good art, and great art can be distinguished and identified' may be accepted in the field, yet the judgement of artistic work or an artist's oeuvre must take into account a much more complex process (1982: 360). The illegitimacy-of-practice argument also helps understand why the rankings of artists, although revived in the twentieth century, have nevertheless remained confined to the margins of the field.

University rankings are an object of much controversy in the contemporary higher education. There are at least three different types of critique addressed at them. The first is a fundamental rejection of rankings as such, in particular as a means of evaluating universities: rankings are seen as 'foreign' forces that pervert the field, produce unwanted power relations, and are overall detrimental (e.g. Halffman and Radder 2015; Münch 2011). The second type of critique is addressed at the commercial nature of some rankers, such as the U.S. News, QS, and Times Higher Education (THE), whose interests in higher education is seen as being motivated mostly or solely by profit (e.g. Dearden et al. 2014). The third type draws attention to the rankings' methodological shortcomings and it is typically accompanied with suggestions for improvement (O'Connell 2013). This type of critique does not in principle reject the idea that rankings can be instrumental in evaluating performances and it can be interpreted as a form of accepting rankings.

Controversies surrounding rankings are certainly hindering their field-wide institutionalization, both in arts and higher education. And yet, despite the critique, rankings continue to occupy a central place in the public discourse in higher education. This may not make rankings more accepted or less contested in the long run, but it may naturalize the discussion on rankings in the field, which can also be seen as a form of institutionalization.

This brief comparative assessment of arts and higher education draws attention to two elements which should be considered when accounting for the institutionalization of rankings in a field. The first one is the rankers themselves, that is, their positions in the field, interests, and the resources at their disposal. In this sense, an art critic, even a contemporary one, is a very different type of entity from the THE (for a detailed discussion, see Ringel et al. 2020). The second one is the varying degree and the nature of their legitimacy in a specific context. 
Although analytically distinct, these two dimensions are not independent. In this sense, rankers can mobilize their resources to strengthen their legitimacy and in doing so work towards the institutionalization of rankings in a specific field. This is, after all, something already evidenced in higher education (Lim 2018; Shahjahan et al. 2020).

A closer look at further commonalities and differences between arts, sports, and higher education-such as the kinds of symbolic (e.g. artistic, scientific) capital, the size and types of audiences (including expert and mass audiences), rankings production and publication practices, the roles of 'gatekeepers', or their effects-could further our understanding of rankings as a broader social phenomenon, but also of the distinctive features of specific fields.

\section{By way of conclusion: a framework for historical and systematic comparative research on rankings}

Based on our analysis on the field-specific trajectories of rankings across the fields of sports, arts, and higher education, it becomes clearer what modern university rankings are about. This allows us to develop a framework for the comparative analysis of rankings in both systematic and historical perspective. As opposed to the early art proto-rankings from the eighteenth century or the early-twentieth century university rankings, modern rankings seem to combine and integrate four sub-operations: zero-sum comparison of performances, quantification, visualization, and repeated publication (Werron and Ringel 2017).

An important feature of this conceptualization of rankings is that it integrates Georg Simmel's triadic model of competition $(1903,1950)$. This model requires the participation of (at least) two competitors struggling for the scarce favour of (at least) a third party whose principal role is to observe and evaluate the competitors' offers. Competitors, in the sense of modern rankings, are imagined as entities with the capacity to act, as opposed to inanimate objects, artefacts, or the deceased (Meyer and Jepperson 2000). All modern rankers have this role in common, yet, as we have seen, the way this role materializes can both change over time and vary across fields. Adding to Simmel's model, our analysis reveals that modern rankings require the existence of not one, but rather two distinct third parties: rankers and their publics (or audiences). Notably, these audiences remain largely fictitious in character and they only exist through being represented by other third parties, such as rankers (see Werron 2010, 2015 for an elaboration). This is not to say that there are no real individuals, who, in the aggregate, amount to an audience; however, our point is that audiences do not 
materialize on their own, but they need to be 'talked into existence' by, for instance, rankers, as well as by policy-makers, deans, alumni and so forth, in order to become socially relevant.

In the previous sections, we illustrated how each of the four sub-operations sets modern rankings apart from the early 'rankings' of artists from the eighteenth century or the earlytwentieth century university rankings. An advantage of this definition is that it allows us to distinguish rankings from other forms of performance evaluation, such as ratings, classifications, standards, and benchmarks (Fourcade 2016). Most importantly, these other types of comparison do not suggest zero-sum relationships. Ratings are not always visualized by means of an open-ended hierarchical table, while rankings exclusively are and this is one of their defining characteristics. To produce and reproduce competition, however, the comparisons of performances need not only to be zero-sum, quantified and visualized, but they also need to be regularly published. Thus, each of the rankings' four sub-operations is a necessary condition, yet none on its own is sufficient for transforming a stable status order into a dynamic competitive field (Brankovic et al. 2018; Werron and Ringel 2017).

This conception of rankings has heuristic implications for in-depth comparative studies on rankings in both systematic and historical perspective. As pointed out earlier, however, when comparing, contrasting, or drawing analogies between rankings across empirical sites, one should be attentive to the elements of variability and its implications for the analysis. For example, rankings are known to construct different types of actors as competitors, notably, individuals, organizations, and nation-states, but also varieties thereof. Relevant audiences, either those discursively constructed by the ranking or real ones, are also known to be different in arts, sports, and higher education, but also across geographical areas, and across time. Rankings vary in many other ways, yet this does not make them incomparable, on the contrary. It is precisely this variability which holds promise of exposing and explaining the dynamics specific to a field, such as higher education.

With this in mind, we propose possible avenues of research which could help contextualize the analysis of university rankings within a broader sociology of rankings. First, future empirical studies on rankings could explore how each sub-operation of modern rankings is embedded in broader discursive environments, such as the novel notions of 'performance' (Verheyen 2018), competition (Werron 2015), and transparency (Ringel 2017), which favour the production of rankings and might have helped institutionalize them across fields. This is also a promising way of addressing the question of how rankings reflect and contribute to long-term societal trends-more promising, in our view, than to simply apply existing macro- 
theoretical framework (such as Bourdieusian field theory) to rankings. While these ideas have to some extent been explored by higher education scholars (e.g. Brankovic 2018; Daraio et al. 2015; Marginson 2006, 2008; Naidoo 2016), the research rarely uses them to establish linkages between higher education and other fields in which rankings play a role.

Second, future research could explore avenues for studying the effects of rankings on organizations in higher education historically and systematically across two or more fields. This could reveal the antecedents and the variability in coupling between, on the one hand, publicly suggested templates of competition such as rankings and, on the other, perceptions, beliefs, and the behaviour of organizations. More importantly perhaps, this would allow us to historically and comparatively contextualize the effects rankings have had on higher education across the world, and advance our understanding of, for example, why rankings as such are more 'successful' in mobilizing attention of policy makers in some parts of the world but not so much in other parts.

Finally, while we have illustrated some advantages of using analogical reasoning, this is merely a glimpse into the potential offered by methods lying beyond the usual linear-causal ones. As a phenomenon spanning a growing number of domains, and not least stretching back in history, rankings are a promising 'vehicle' for identifying and examining similarities, differences, as well as linkages between fields. Given the centrality of higher education studies on rankings in the wider 'family' of rankings studies, higher education scholarship is in an excellent position to contribute to broader discussions on rankings and related phenomena. 


\section{References}

Bartha, P. (2019), 'Analogy and Analogical Reasoning', in Stanford Encyclopedia of Philosophy, accessed 25 June 2020 at https://plato.stanford.edu/entries/reasoninganalogy/\#PraJus.

Becker, H. S. (1982), Art Worlds, Berkeley and LA, CA: University of California Press.

Becker, H. S. (2014), What About Mozart? What About Murder? Reasoning from Cases, Chicago, IL: University of Chicago Press.

Beniger, J. R. and D. L. Robyn (1978), 'Quantitative Graphics in Statistics: A Brief History', The American Statistician, 32 (1), 1-11.

Bourdieu, P. (1996), The Rules of Art: Genesis and Structure of the Literary Field, Stanford, CA: Stanford University Press.

Brankovic, J. (2018), 'The status games they play: unpacking the dynamics of organisational status competition in higher education', Higher Education, 75 (4), 695-709.

Brankovic, J., L. Ringel and T. Werron (2018), 'How rankings produce competition: The case of global university rankings', Zeitschrift für Soziologie, 47 (4), 270-88.

Buchholz, L. (2016), 'What is a global field? Theorizing fields beyond the nation-state', The Sociological Review Monographs, 64 (2), 31-60.

Buckermann, P. (2018), 'Reactions, reactivity, rampant reductions. On self-fulfilling prophecies, the Matthew effect, and global potentials of a new gallery ranking', Creative Industries Journal, 11 (2), 197-202.

Cantwell, B. (2020), 'Explanatory accounts in international and comparative higher education research', Higher Education Quarterly, 74 (2), 149-61.

Daraio, C., A. Bonaccorsi and L. Simar (2015), 'Rankings and university performance: A conditional multidimensional approach', European Journal of Operational Research, $244(3), 918-30$.

Daston, L. (1992), 'Objectivity and the Escape from Perspective', Social Studies of Science, 22 (4), 597-618.

de Rijcke, S., I. Wallenburg, P. Wouters and R. Bal (2016), 'Comparing Comparisons. On Rankings and Accounting in Hospitals and Universities', in J. Deville, M. Guggenheim, and Z. Hrdličková (eds), Practising Comparison: Logics, Relations, Collaborations, Manchester: Mattering Press.

Dearden, J. A., R. Grewal and G. L. Lilien (2014), 'Framing the university ranking game: actors, motivations, and actions', Ethics in Science and Environmental Politics, 13 (2), 131-9.

Deville, J., M. Guggenheim and Z. Hrdličková (eds.) (2016), Practising Comparison: Logics, Relations, Collaborations, Manchester: Mattering Press. 
Elsbach, K. D. and R. M. Kramer (1996), 'Members' Responses to Organizational Identity Threats: Encountering and Countering the Business Week Rankings', Administrative Science Quarterly, 41 (3), 442-76.

Espeland, W. N. and M. Sauder (2007), 'Rankings and Reactivity: How Public Measures Recreate Social Worlds', American Journal of Sociology, 113 (1), 1-40.

Fourcade, M. (2016), 'Ordinalization: Lewis A. Coser Memorial Award for Theoretical Agenda Setting 2014', Sociological Theory, 34 (3), 175-95.

Guttmann, A. (1978), From Ritual to Record: The Nature of Modern Sports, New York: Columbia University Press.

Halffman, W. and H. Radder (2015), 'The Academic Manifesto: From an Occupied to a Public University', Minerva, 53 (2), 165-87.

Hammarfelt, B., S. de Rijcke and P. Wouters (2017), 'From Eminent Men to Excellent Universities: University Rankings as Calculative Devices', Minerva, 55 (4), 391-411.

Hazelkorn, E. (2015), Rankings and the Reshaping of Higher Education: The Battle for WorldClass Excellence, Dordrecht: Springer.

Hinds-Aldrich, M. (2012), 'Teaching Theory Analogically: Using Music to Explain Criminological Theory', Journal of Criminal Justice Education, 23 (4), 481-99.

Jeacle, I. and C. Carter (2011), 'In TripAdvisor we trust: Rankings, calculative regimes and abstract systems', Accounting, Organizations and Society, 36 (4-5), 293-309.

Kelley, J. G. and B. A. Simmons (2015), 'Politics by Number: Indicators as Social Pressure in International Relations', American Journal of Political Science, 59 (1), 55-70.

King, B. G., T. Felin and D. A. Whetten (2009), 'Comparative organizational analysis: An introduction', in B. G. King, T. Felin, and D. A. Whetten (eds), Studying Differences between Organizations: Comparative Approaches to Organizational Research, vol. 26, Bingley: Emerald Group Publishing Limited, pp. 3-19.

Kornberger, M. and C. Carter (2010), 'Manufacturing competition: how accounting practices shape strategy making in cities', Accounting, Auditing \& Accountability Journal, 23 (3), 325-49.

Kosmützky, A. (2015), 'In defence of international comparative studies. On the analytical and explanatory power of the nation state in international comparative higher education research', European Journal of Higher Education, 5 (4), 354-70.

Kosmützky, A. and T. Nokkala (2020), 'Towards a methodology discourse in comparative higher education', Higher Education Quarterly, 74 (2), 117-23.

Kosmützky, A., T. Nokkala and S. Diogo (2020), 'Between context and comparability: Exploring new solutions for a familiar methodological challenge in qualitative comparative research', Higher Education Quarterly, 74 (2), 176-92. 
Krause, M. (2016), 'Comparative Research: Beyond Linear-causal Explanation', in J. Deville, M. Guggenheim, and Z. H. Hrdličková (eds), Practising Comparison: Logics, Relations, Collaborations, Manchester: Mattering Press, pp. 45-67.

Lamont, M. (2012), 'Toward a Comparative Sociology of Valuation and Evaluation', Annual Review of Sociology, 38 (1), 201-21.

Lim, M. A. (2018), 'The building of weak expertise: the work of global university rankers', Higher Education, 75 (3), 415-30.

Linstead, S. (1994), 'Objectivity, Reflexivity, and Fiction: Humanity, Inhumanity, and the Science of the Social', Human Relations, 47 (11), 1321-46.

Lynch, K. (2015), 'Control by numbers: new managerialism and ranking in higher education', Critical Studies in Education, 56 (2), 190-207.

Mahoney, J. and D. Rueschemeyer (2003), Comparative Historical Analysis in the Social Sciences, Cambridge: Cambridge University Press.

Marginson, S. (2006), 'Dynamics of National and Global Competition in Higher Education', Higher Education, 52 (1), 1-39.

Marginson, S. (2008), 'Global field and global imagining: Bourdieu and worldwide higher education', British Journal of Sociology of Education, 29 (3), 303-15.

Mennicken, A. and W. N. Espeland (2019), 'What's New with Numbers? Sociological Approaches to the Study of Quantification', Annual Review of Sociology, 45 (1), 22345.

Meyer, J. W. and R. L. Jepperson (2000), 'The "Actors" of Modern Society: The Cultural Construction of Social Agency', Sociological Theory, 18 (1), 100-20.

Monks, J. and R. G. Ehrenberg (1999), 'U.S. News \& World Report's College Rankings Why They Do Matter', Change, 31 (6), 42-51.

Münch, R. (2011), Akademischer Kapitalismus: Zur Politischen Ökonomie Der Hochschulreform, Berlin: Suhrkamp.

Myers, L. and J. Robe (2009), College Rankings: History, Criticism and Reform, Washington, DC: Center for College Affordability and Productivity, p. 51, March.

Naidoo, R. (2016), 'The competition fetish in higher education: varieties, animators and consequences', British Journal of Sociology of Education, 37 (1), 1-10.

O'Connell, C. (2013), 'Research Discourses Surrounding Global University Rankings. Exploring the Relationship with Policy and Practice Recommendations', Higher Education, 65 (6), 709-23.

Pinheiro, R., L. Geschwind, F. O. Ramirez and K. Vrangbæk (2016), 'The Value in Comparing Organizational Fields and Forms', in R. Pinheiro, L. Geschwind, F. O. Ramirez, and K. Vrangbæk (eds), Towards a Comparative Institutionalism: Forms, Dynamics and Logics Across the Organizational Fields of Health Care and Higher Education, vol. 45, Bingley: Emerald Group Publishing Limited, pp. 9-32. 
Quak, S., J. Heilbron and J. Meijer (2019), 'Ranking, coordination, and global governance: The case of the Access to Medicine Index', Business and Politics, 21 (2), 172-204.

Ragin, C. and D. Zaret (1983), 'Theory and Method in Comparative Research: Two Strategies', Social Forces, 61 (3), 731-54.

Ramirez, F. O. and J. W. Meyer (2013), 'Universalizing the University in a World Society', in J. C. Shin and B. M. Kehm (eds), Institutionalization of World-Class University in Global Competition, Dordrecht: Springer Netherlands, pp. 257-73.

Rindova, V. P., L. L. Martins, S. B. Srinivas and D. Chandler (2018), 'The Good, the Bad, and the Ugly of Organizational Rankings: A Multidisciplinary Review of the Literature and Directions for Future Research': , Journal of Management, 44 (6), accessed at https://doi.org/10.1177/0149206317741962.

Rindova, V. P., I. O. Williamson, A. P. Petkova and J. M. Sever (2005), 'Being Good or Being Known: An Empirical Examination of the Dimensions, Antecedents, and Consequences of Organizational Reputation', Academy of Management Journal, 48 (6), 1033-49.

Ringel, L. (2017), Transparenz als Ideal und Organisationsproblem: Eine Studie am Beispiel der Piratenpartei Deutschland, Wiesbaden: Springer VS.

Ringel, L., J. Brankovic and T. Werron (2020), 'The Organizational Engine of Rankings: Connecting "New" and "Old" Institutionalism', Politics and Governance, 8 (2), 36-47.

Ringel, L. and T. Werron (2020), 'Where Do Rankings Come From? A Historical-Sociological Perspective on the History of Modern Rankings', in A. Epple, W. Erhart, and J. Grave (eds), Practices of Comparing: Towards a New Understanding of a Fundamental Human Practice, Bielefeld: Bielefeld University Press, pp. 137-70.

Shahjahan, R. A. and A. J. Kezar (2013), 'Beyond the "National Container": Addressing Methodological Nationalism in Higher Education Research', Educational Researcher, 42 (1), 20-9.

Shahjahan, R. A., E. L. Sonneveldt, A. L. Estera and S. Bae (2020), 'Emoscapes and commercial university rankers: the role of affect in global higher education policy', Critical Studies in Education, accessed 11 April 2020 at https://www.tandfonline.com/doi/abs/10.1080/17508487.2020.1748078.

Shore, C. and S. Wright (2015), 'Audit Culture Revisited: Rankings, Ratings, and the Reassembling of Society', Current Anthropology, 56 (3), 421-44.

Simmel, G. (1903), 'Soziologie der Konkurrenz', Neue Deutsche Rundschau (Freie Bühne), 14 (10), 1009-23.

Simmel, G. (1950), The Sociology of Georg Simmel, New York, NY: Simon and Schuster.

Soh, K. C. (2011), 'Don't read university rankings like reading football league tables: Taking a close look at the indicators', Higher Education Review, 44 (1), 15-29.

Spoerhase, C. (2018), 'Rankings: A Pre-History', New Left Review, 114, 99-113. 
Stinchcombe, A. L. (1978), Theoretical Methods in Social History, New York, NY: Academic Press Inc.

Sunstein, C. R. (1993), 'On Analogical Reasoning', Harvard Law Review, 106 (3), 741-91.

Swedberg, R. (2016), 'Before theory comes theorizing or how to make social science more interesting', The British Journal of Sociology, 67 (1), 5-22.

Teichler, U. (2014), 'Opportunities and problems of comparative higher education research: the daily life of research', Higher Education, 67 (4), 393-408.

Tight, M. (2000), 'Do League Tables Contribute to the Development of a Quality Culture? Football and Higher Education Compared', Higher Education Quarterly, 54 (1), 22-42.

Usher, A. (2016), 'A short global history of rankings', in E. Hazelkorn (ed), Global Rankings and the Geopolitics of Higher Education: Understanding the Influence and Impact of Rankings on Higher Education, Policy and Society, New York, NY: Routledge, pp. 2353.

Vaughan, D. (2004), 'Theorizing Disaster: Analogy, historical ethnography, and the Challenger accident', Ethnography, 5 (3), 315-47.

Vaughan, D. (2014), 'Analogy, Cases, and Comparative Social Organization', in R. Swedberg (ed), Theorizing in Social Science: The Context of Discovery, Stanford, CA: Stanford University Press, pp. 61-84.

Verheyen, N. (2018), Die Erfindung der Leistung, Berlin: Hanser Berlin.

Webster, D. S. (1986), Academic Quality Rankings of American Colleges and Universities, Springfield, IL: Charles C. Thomas.

Weick, K. E. (1995), 'What Theory is Not, Theorizing Is', Administrative Science Quarterly, 40 (3), 385-90.

Werron, T. (2009), 'World Sport and its Public. On Historical Relations of Modern Sport and the Media', in U. Wagner, R. Storm, and J. Hoberman (eds), Observing Sport. Modern System Theoretical Approaches, Schorndorf: Hofmann, pp. 33-60.

Werron, T. (2010), 'Direkte Konflikte, indirekte Konkurrenzen / Direct Conflict, Indirect Competition', Zeitschrift Für Soziologie, 39 (4), 302-18.

Werron, T. (2013), 'Die Liga': Entstehung, Funktionen und Schwächen eines Konkurrenzmodells', in P. Wolfram (ed), Geschichte Des Fußballs in Deutschland Und Europa Seit 1954, Stuttgart, pp. 51-83.

Werron, T. (2015), 'Why do we believe in competition? A historical-sociological view of competition as an institutionalized modern imaginary', Distinktion: Journal of Social Theory, 16 (2), 186-210.

Werron, T. and L. Ringel (2017), 'Rankings in a comparative perspective. Conceptual remarks', in S. Lessenich (ed), Geschlossene Gesellschaften. Verhandlungen Des 38. Kongresses Der Deutschen Gesellschaft Für Soziologie, Essen: DGS. 